\title{
Enhancing Elementary Level Student's Expressive Movement Capability through Creative Approach
}

\author{
Yuliasma \\ Faculty of Language and Arts, \\ State University of Padang \\ Jl. Prof. Dr. Hamka, Air Tawar Barat,Padang, Sumatera Barat 25131, Indonesia \\ E-mail : yolyole63@gmail.com
}

\begin{abstract}
Dance can have great influences on children's life as it includes the physical activities as well as a medium for selfexpression. However, problems usually can be found in dance education at elementary level, including the lack of interest of the student and the perception that dancing is difficult and not comfortable. This paper reports a study on inducing creative approach to inc rease student's expressive movement capability, in the form of storytelling. The method has been applied in few sessions of dancing class at State Elementary School No. 2, LubukBuaya, Padang, West Sumatera, Indonesia. The analysis on the capability test shows that there was significant increment on the expressive movement capability of the students after the method was applied. This was shown by the final performance test result that $90 \%$ of the students were able to develop their own unique movements developed them into beautiful patterns, and performed the movements smoothly.
\end{abstract}

\section{Keywords-Expressive movements, creative dance, dance education, elementary student}

\section{INTRODUCTION}

Creative dance is currently an exceptional contemporary pedagogical and teaching approach which assists and supports significantly the harmonious kinetic development of individuals. Moreover, it is an amusing educational tool that contributes to the establishment of fundamental motor skills in fostering coordination, cooperation and team co-responsibility, psychomotor development and in the creation of a pleasant teaching environment (Lykesas et. al., 2014).

For children, movement and dance program provides the opportunity to obtain creative and complex motor experiences, regardless of their abilities. Movement is a basic form of experience and communication (Koff 2000). When movement becomes dance, it facilitates the acquisition of sensory, motor, cognitive, social and emotional skills either as individual skill or as a coherent integrated development experience. Movement through dance helps children to learn about their bodies and how to express through it, the body becomes the communication vehicle of the young child who expresses feelings and communicates with its environment (Lutz and Kuhlam 2000). Moreover, it teaches children how to handle different situations such as motor planning, problem solving or social interactions (Lorenzo-Lasa et al. 2007; Justo 2008; Cheung 2010; Spanaki et al. 2010).

However there are studies that identify a negative attitude and indifference of students for dance (Graham 1995). The majority of studies indicate, however, that an educational program that includes creative dance activities, is characterized by student's willingness to discover, explore, collaborate and create a pleasant climate. It has a positive effect on the acceptance of dance as a subject but also to the improvement their motor skills (Capel 1986; Nieminem 1997; Cheung 2010).

\section{Study Case}

Based on preliminary research and discussion, at the State Elementary School No 2, LubukBuaya, Padang, the dance education can be described as follows:

1. Dancing education is emphasizing more toward cognitive learning process, such as introduction to dancing, function, theoretical implementation, etc.

2. Practical learning was limited on co-curriculum activities, and more oriented toward the teacher, in sense that the teacher learn the movement and the students follow the teacher.

3. Dance education was not fit with the student's motoric movement capability and hence there was pressure in doing the dance movement. This situation has created some effects on the students, as listed below.

4. The students did not know that dance comprises movement which are created through the body to express human feelings including happiness, sadness, anger and fear, in form of symbolic movements that has been explored and arranged as esthetic movements.

5. The students did not understand that esthetic movements require power control to create movement character, including strong, soft, sharp and supple.

6. The students did not know that all of human movements can be arranged to form a dance. They only think that learning to dance is a difficult process. 
7. The students were not trained to develop their own creative movements, nor to explore the movements to create a meaningful movement sequence to form a dance. The situation also introduced some effect on the teachers, including:

a. The teachers were unable to develop student's creativity to express themselves in form of movements.

b. The teachers were unable to motivate the students to create their own movement as a self-expression. From phenomena listed above, some problems has been formulated in this research, as follows:

1) Students were lack of eagerness to learn movements.

2) Students were afraid to express themselves through movements.

3) Students were not trained to decide the suitable movements from their own exploration.

4) Students were more mimicking the teacher's movements, and the learning process is more oriented toward the teachers.

5) Students were learn more on dance forms.

To solve the formulated problems, some activities have been conducted. The main objective is to determine if creative approach may increase the student's expressive movement capability in dance education at the State Elementary School No. 2 Lubuk Buaya Padang, West Sumatera, Indonesia. The objective can be specified for the students and the teachers, as listed below.

1. To support the development of student's social, mental and motoric capability.

2. To increase the student's expressive movement capability in dance learning process.

3. To increase the teacher's understanding regarding student motoric capability and their movement characteristic and hence able to develop student's movement capability.

4. To increase the teacher's interest on creating creative dance.

\section{METHOD}

Murray (1975) states that in creative dance learning process the student should be motivated to do movement discovery through movement exploration either individually or in group. Moreover, the student is expected to be able to conduct problem solving in the learning process. Adopting this theory, some stages has been prepared in this research to be applied in the dance learning process which were expected to increase the student's expressive movement capability based on their motoric movement ability. The stages includes:

1. Motivating. Smith theory (1985) has been utilized by applying ideational stimulus to provide preliminary experience or concept for a particular research.

2. Exploration. Movements were found through exploration.

3. Problem solving. Students were guided to make decision from movement exploration to creative movement, expressive that fit with the student's motoric capability.

The argument to choose these stages was based on the objective of this research, which was to increase the student's capability in creating expressive movement, creative and esthetic. Success indicator of this method comprises:

1. Through the teacher's guidance, students have the interest and courage to do symbolic movement fit with their motoric capabilities. The students should feel no pressure in expressing the movements. The students have their freedom to find their own personal movements. Practical tests were given to determine the student's capability in finding movements based on the stimulant provided to them.

2. Students are able to do various movements based on imaginative ideas given by the teacher accompanied by a certain regular beat of sound. Practical tests were also given to determine the student's capability in developing movement patterns based on their imaginative creativities.

Cycle model developed by Kemmis and McTaggart (1988) has been adopted in this research. The stages comprises of plan, action, observation and reflection. In this research, the cycle was applied twice. First cycle was conducted in four class sessions while the second cycle was conducted in two class sessions. Duration of each session was 90 minutes. Total number of the participants in the class were 40 students.

\section{A. Plan}

The research was planned based on orientation results which were selected to suit the problems formulation. There were preparation needed to conduct the cycle.

1. Reviewing the subject syllabus, constructing the teaching material and determining the minimum achieved competence.

2. Arranging the class presentation by adopting creative approach and to decide the materials which were presented by the researchers (including the teachers).

3. Creating an observational guidance in form of lists of the observed student's behavior during the class sessions. 
4. Setting up practical test on the student's expressive movement capability.

5. Preparing the facilities and supporting equipment needed in the learning process.

B. Action

The method was applied during the dance class sessions. Some activities have been conducted as described in the following example:

1. The session was started with teacher explained thing related with dance learning process to the students.

2. It was followed by stretching, to prepare the student's body for the movement learning.

3. Teacher told a story about going to a coconut farm through a paddy field.

4. Teacher raised the student's fantasy by imagining that everybody were walking in the paddy field.

5. Teacher instructed the students to move as if they were walking in the paddy field.

6. Teacher choose some of the student's unique movements which can be used as preliminary pattern of walking in the paddy field.

7. Teacher instructed the students to mimic the chosen movements while in the same time encouraged the students to keep trying develop their own unique personal movement.

8. Teacher and students repeated the movement of walking in the paddy field and watch the coconut trees accompanied by music.

\section{Observation}

In this research, data were collected through direct observation on the students, field note and interview, pictures and videos, and performance test. This method was adopted and modified from Giguere (2011). Observation was conducted in collecting the data regarding student's reaction when they were instructed to arrange the movements together with the teacher. Table 1 shows the observed aspect in the learning process.

Field note is a daily journal written by the researcher to record the setting of learning process. Pictures and videos were also taken to support the field note.

\section{Data Analysis}

How active the students (or activity level) in the class was measured by utilizing Equation 1 Sudjana (1991): (Eq. 1)

A = Activity level

$\mathrm{F}=$ Number of active student

$\mathrm{N}=$ Total number of student in the class

Mahmud (1994) divide activity into four categories:

$1 \%-25 \%=$ Very low activity level

$26 \%-50 \%=$ Low activity level

$51 \%-75 \%=$ High activity level

$76 \%-100 \%=$ Very high activity level

Student's expressive movement capability was analyzed by using descriptive statistical method. To see the difference between before and after the method was applied, mean score technique was employed. In this research, the target was to achieve $70 \%$ active students from the total students able to develop their own expressive movement.

Data about student's movement exploration until become expressive movements were obtained through performance test after the learning process were finished. The test also included measurement on the student's expressive movement capability to see how far the students had been progressed with the learning material. Some aspects which were graded comprises development, originality and fluency. The expected minimum average score from the test was 75.

\section{E. Reflection}

After results from the first cycle were obtained and the data were analyzed, all of the positive and negative things occurred in the first cycle were listed. All of advantages and disadvantages were considered to develop a revised plan for the second cycle. It included some revision to refine the method applied in the first cycle. 


\section{FINDINGAND DISCUSSION}

Table 2, 3, 4 and 5 represents the data obtained from the first cycle. They respectively shows the statistic related with the activeness of the students when teacher presents the topic in the class, student's activeness in exploring the movements, student's positive and negative mental attitudes.

From Table 2, it can be seen that the students were become more active in the classes as the session increases. They became more focus in listening the teacher, responsive in answering the questions as well as asking some questions to the teacher. There was significant increment of the number active students in the class, from only $40 \%$ in the first session to $87.5 \%$ in the last session.

The number of students who actively exploring the movements were also increases, as can be seen in Table 3 . In the first session, there was only $45 \%$ students who were active in the movement exploration while in the last session, the number of active students were increases to $90 \%$. This percentage was higher from the target and hence it can be conclude that the objective regarding student's ability to develop their own expressive movement has been achieved.

It was also observed that as the sessions progressed, the number of students who seemed to be happy in the class increases, and the students who were reluctant and ignorant toward to topic became less. Table 4 and 5 represent data on the student's positive and negative mental attitudes respectively.

In the end of the first cycle, performance test on the student's expressive movement capability was conducted. On average, the obtained score by the students were 68.97 , which was below than the targeted average score. For this reason, the second cycle was conducted.

Before the second cycle was started, data from the first cycle were analyzed and some notes were taken to be considered in the second cycle preparation. These notes can be summarized as follows:

1. The students were still in doubt, worried and had no confidence to create and show their movements.

2. Only few students had the courage and initiative to develop their own unique movements, while the rest of the students were only imitating.

3. Learning process was still dominated by the teacher, in sense that the teacher were more active to push and encourage the students to learn the topic while the students were only following the teacher instructions.

4. As the learning process progressed, the students understood that dance is not difficult and can be done based on their own movement abilities.

5. There was positive progress on the students toward the given topic, as they became more interested and active in learning the dance.

From the reflection, it was concluded that there were some considerations needed to improve the applied method. First, the method in motivating the students to create the movements should be improved. With the original method, only few students were able to develop their own unique movements, while the rest were only imitating. Second, there were good improvement in the student's activeness in developing their own expressive movements. However, many of them were still unsure and worried to do the movements, especially when the movements were accompanied with beat or music. They were afraid that they will do a wrong movement. Lastly, the number who were enjoyed and felt happy with the class increases as the sessions progressed. However, their courage still needs to be improved.

Based on these reasons, there was a modification in the method for the second cycle. In the first cycle, the students were motivated to develop their expressive movements through ideational stimulus in form of stories. While it has been successfully increase the activeness of the students to develop the movements, the student's expressive movement capability was still below expectation. Hence, the focus on the second cycle was to improve the student's expressive movement capability by motivating the students to expand the developed movements into something which was more organized and have particular pattern. The learning process was more oriented on the students, while the teacher was acting only as a motivator and facilitator. As a motivator, the teacher encouraged the students to be more active in finding their own unique movement, developed and expanded the movements into beautiful patterns and emphasized that there is no "wrong" movements. As a facilitator, the teacher helped the students to decide the movements which were more suitable with the student's motoric capabilities.

In the end of the second cycle, performance test on the student's expressive movement capability was conducted again. On average, the obtained score by the students were 90 , which was much higher than the targeted average score. Hence, the method was a success, indicated by the high increment on the number of the students who were able to develop their own unique movements, and expanded it into beautiful patterns, and the fluency to do the movements.

\section{CONCLUSION AND RECOMMENDATION}

Enhancement on student expressive movement capability through creative approach on dance education at elementary level has been presented in this paper. The method has been successfully increase the number of students at the 02 State Elementary School of Lubuk Buaya Padang, West Sumatera, Indonesia, who were capable to develop their own unique movements, expanded it into beautiful pattern and fluently did the movements, suits with their own motoric capabilities. With the proposed method, teacher in the class were improved in presenting the dance topic and became more active in creating creative students. Students 
who were originally reluctant in dancing became interested and active, while the students who were already active from the beginning became more creative in doing the dance.

\section{References}

Kridalaksana, H. (2008). Kamus linguistik. Jakarta: PT Gramedia Pustaka Utama.

Machali, R. (2000). Pedoman bagi penerjemah. Jakarta: Gramedia Widiasarana Indonesia.

Manaf, N. A. (2002). Persepsi kesantunan tindak tutur memCapel, S. 1986. "Education gymnastics meeting, physical education goals." Journal of Education, Recreation \& Dance 57 (2): 34-38. doi: 10.1080/07303084.1986.10606041.

Cheung, R.H.P. 2010. "Designing movement activities to develop children's creativity in early childhood education." Early Child Development and Care 180 (3): 377-385. doi: 10.1080/03004430801931196.

Giguere, M. (2011). "Social influences on the creative process: An examination of children's creativity and learning in dance." International Journal of Education and the Arts 12 (SI 1.5). Accessed 7 January 2016. http://www.ijea.org/v12si1/.

Graham, G. (1995). "Physical education through student's eyes and in student voices." Journal of Teaching in Physical Education 14: $364-371$.

Justo, C.F. (2008). "Creative relaxation, motor creativity, self-concept in a sample of children from early childhood Education." Electronic Journal of Research in Educational Psychology 6 (1) no. 14: 29- 50.

Kemmis, S. and McTaggart, R. (1988). The Action Research Reader. 3rd ed. Victoria: Deakin University Press.

Koff, S. (2000). "Toward a definition of dance education.” Childhood Education 77 (1): 27-31. doi: 10.1080/00094056.2000.10522134.

Lorenzo-Lasa, R., Ideishi, R. I., and Ideishi S. K. 2007. "Facilitating Preschool Learning and Movement through Dance." Early Childhood Education Journal 35 (1): 25-31. doi: 10.1007/s10643-007-0172-9.

Lutz, T., and Kuhlman, W. D. 2000. "Learning About Culture Through Dance in Kindergarten Classrooms.” Early Childhood Education Journal 28 (1): $35-40$. doi: 10.1023/A:1009595520022.

Lykesas, G., Tsapakidou, A., and Tsompanaki, E. 2014. "Creative Dance as a Means of Growth and Development of Fundamental Motor Skills for Children in First Grades of Primary Schools in Greece.” Asian Journal of Humanities and Social Studies 02 (01): 211-218.

Mahmud, D. 1994. Psikologi Pendidikan [Educational Psychology]. Yogyakarta: Rake Press.

Murray, R. 1975. Dance Elementary. 3rd ed. New York: Harper and Row.

Nieminem, P. 1997. "Participation profiles and socialism into dance among non-professional dancers." Sport Education and Society 2 (2): $221-234$.

Smith, J. 1985. Dance Composition: A Practical Guide for Teachers. London: A \& C Black.

Spanaki, E., Skordilis, E., and Venetsanou, F. 2010. "The Effect of a Psychomotor Program on the Motor Proficiency of Early Elementary School Children." Inquiries in Physical Education \& Sport 8 (2): 132-141.

Sudjana, N. 1991. Evaluation of Teachers. Bandung: Remaja Rosdakarya.erintah dalam bahasa Indonesia. Wacana, 4 (2), 174-191.

Pusat Bahasa Departemen Pendidikan Nasional RI. (2008). Kamus besar bahasa Indonesia edisi keempat. Jakarta: PT Gramedia Pustaka Utama.

Ramadhan., S. (2007). Representasi kesantunan tindak tutur berbahasa Indonesia guru dalam pembelajaran di kelas (kajian etnografi komunikasi di SMA PMT Hamka Padang Pariaman). Malang: Program Pascasarjana Universitas Negeri Malang.

Spradley, J. P. (1980). Participant observation. New York: Holt, Rinehart and Winston.

TABLE 1. THE OBSERVED ASPECT IN THE LEARNING PROCESS

\begin{tabular}{|c|c|c|}
\hline & \multicolumn{2}{|c|}{ Observed Behavior } \\
\hline Teacher presents the topic in the class & Active & Not active \\
\hline Exploring the movements & Active & Not active \\
\hline Positive mental attitude & Happy \\
\hline Negative mental attitude & Reluctant & Eager \\
\hline
\end{tabular}

TABLE 2. STUDENT'S ACTIVENESS WHEN TEACHER PRESENTS THE TOPIC IN THE CLASS

\begin{tabular}{|c|c|c|}
\hline & \multicolumn{2}{|c|}{ Observed Behavior } \\
\hline & Active (\%) & Not active (\%) \\
\hline Session I & 40 & 60 \\
\hline Session II & 55 & 45 \\
\hline Session III & 70 & 30 \\
\hline Session IV & 87.5 & 12.5 \\
\hline
\end{tabular}

TABLE 3. STUDENT'S ACTIVENESS TO EXPLORE THE MOVEMENTS

\begin{tabular}{|c|c|c|}
\hline & \multicolumn{2}{|c|}{ Observed Behavior } \\
\hline & Active (\%) & Not active (\%) \\
\hline Session I & 45 & 55 \\
\hline Session II & 52.5 & 47.5 \\
\hline Session III & 75 & 25 \\
\hline Session IV & 90 & 10 \\
\hline
\end{tabular}

TABLE 4. STUDENT'S POSITIVE MENTAL ATTITUDE

\begin{tabular}{|c|c|c|}
\hline & \multicolumn{2}{|c|}{ Observed Behavior } \\
\hline & Happy (\%) & Not happy (\%) \\
\hline Session I & 55 & 45 \\
\hline Session II & 65 & 35 \\
\hline Session III & 80 & 20 \\
\hline Session IV & 87.5 & 12.5 \\
\hline
\end{tabular}


TABLE 5. STUDENT'S NEGATIVE MENTAL ATTITUDE

\begin{tabular}{|c|c|c|}
\hline & \multicolumn{2}{|c|}{ Observed Behavior } \\
\hline & Reluctant (\%) & Eager (\%) \\
\hline Session I & 50 & 50 \\
\hline Session II & 37.5 & 62.5 \\
\hline Session III & 12.5 & 87.5 \\
\hline Session IV & 0.75 & 99.25 \\
\hline
\end{tabular}

